\title{
The energy metabolism of sheep walking on the level and on gradients
}

\author{
BY J. L. CLAPPERTON \\ Hannah Dairy Research Institute, Ayr \\ (Received 24 April 1963-Accepted 2 October 1963)
}

Although many investigations have been made, notably by Brody and his associates (Brody, 1945), of the energy cost and energetic efficiency of muscular work in the larger farm animals, horses, mules and cattle, no systematic studies have been made with sheep and goats. It was to try to fill this gap that this investigation was begun.

The net efficiency of muscular work is defined as the ratio of the work done to the energy expended in doing it. Work is defined as force $\times$ distance, and can be expressed in units of energy by use of the mechanical equivalent of heat, i.e. I $\mathrm{kg} \mathrm{m}$ work $=2 \cdot 34$ cal. It is impossible to assess in any simple way how much external work is done by an animal walking horizontally and, therefore, it is not possible to measure the efficiency of an animal for horizontal walking. Measurements made with animals walking on gradients, however, permit an assessment of efficiency because the energy expended in raising the body can be equated with its gain in potential energy. To estimate the energetic efficiency of muscular work thus involves measurement of energy expenditure when the animal walks on the level and on gradients.

\section{EXPERIMENTAL}

Animals. Two Cheviot wether sheep, each weighing approximately $90 \mathrm{lb}$, were used. One of them (sheep $\mathrm{H}$ ) was well accustomed to walking on a treadmill having been used in previous experiments and the other (sheep J) was trained to walk over a period of I week before the experiment began. Both sheep were used to living in cages and respiration chambers.

Diets. Each sheep was given a ration of artificially dried grass finely ground and pelleted; it contained $15.1 \%$ crude protein on a dry-matter basis. Two amounts were given to each sheep. One, referred to as the high level, was computed to be sufficient to allow the animal to retain energy even when working at the highest rate; the other, referred to as the low level, was computed to result in loss of energy from the body even when the sheep was at rest. Each of the rations was offered for 14 days before the experiment began. Food was given twice daily at $5 \mathrm{pm}$ and $5.30 \mathrm{am}$. No refusal of food occurred during the experiments. The experiments with the two amounts of food were duplicated with each sheep and the amounts of food given and the order in which they were offered are shown in Table $\mathrm{I}$.

Amount of exercise. Exercise was imposed for about $4 \mathrm{~h}$ daily in each experiment, 
the approximation being the result of adjustments made to maintain constant the amount of work done. If the sheep walked for a constant time on a treadmill travelling at constant speed, its horizontal movement would be less if the belt was inclined than if it was level. In these experiments the horizontal component was kept constant and so the sheep had perforce to travel longer on inclines than on the level. The differences in the length of the exercise period due to this adjustment were small, less than $\mathrm{x} \%$. In addition to this adjustment an attempt was made to maintain constant from day to day the absolute work load imposed on each sheep irrespective of variation in its weight. The duration of the working periods was varied in inverse proportion to the weight of the sheep. The standard work load of sheep $\mathrm{H}$ was greater than that of sheep J. The most work performed by sheep $\mathrm{H}$ entailed $256 \mathrm{~min}$ of walking at the highest speed and steepest gradient. This was equivalent to walking $12.43 \mathrm{~km}(7 \cdot 7$ miles) and ascending $1130 \mathrm{~m}(3700 \mathrm{ft})$ in the day.

\section{Table I. Dried grass offered to the two sheep}

\begin{tabular}{|c|c|}
\hline \multicolumn{2}{|c|}{ Sheep H } \\
\hline $\begin{array}{l}\text { Period } \\
\text { no. }\end{array}$ & $\begin{array}{c}\mathrm{g} \text { dry } \\
\text { matter/day }\end{array}$ \\
\hline I & 529 \\
\hline 3 & 978 \\
\hline 5 & 978 \\
\hline 7 & 529 \\
\hline
\end{tabular}

$\begin{array}{cc}\begin{array}{c}\text { Period } \\ \text { no. }\end{array} & \text { Sheep J } \\ 2 & 930 \\ 4 & 449 \\ 6 & 449 \\ 8 & 886\end{array}$

Observations and their standardization. On each day the production of carbon dioxide and methane and the consumption of oxygen were measured. This was done in two subperiods, one of $470 \mathrm{~min}$ during the day when the work was performed and one during the night of $945 \mathrm{~min}$ when no work was done. These subperiods are referred to as 'day' and 'night' respectively; feeding occurred once in each subperiod. The two subperiods add up to $23 \mathrm{~h} 35 \mathrm{~min}$; the remaining 25 min each day were used to adjust the respiration apparatus. The reason for the subdivision of the day was to examine whether severe exercise in the preceding $8 \mathrm{~h}$ affected metabolism in the subsequent $\mathrm{I} 6 \mathrm{~h}$. To help in the interpretation of the heat productions measured in the latter period, the time the sheep spent lying was recorded automatically by means of an elastic connexion to a switch operating an electric clock.

Faeces were collected daily, and since it has been shown (Clapperton, 1964) that exercise has only little effect on the apparent digestibility of food, the daily samples were pooled over 6-day periods and the $\mathrm{C}$ and $\mathrm{N}$ contents and heat of combustion determined on the pooled sample. Urine was collected and its $\mathrm{N}$ content determined daily. Samples of urine were also pooled for the determination of $\mathrm{C}$ and heat of combustion over 6 -day periods. Analytical methods were those previously described (Clapperton, 1964).

Design of experiment. The experiments were made in a respiration chamber fitted with a treadmill in which the belt was supported on rollers. When each of the rations was given nine experimental treatments were imposed. These comprised all combina- 
tions of three speeds of belt movement of the treadmill and three inclinations of the belt. The three speeds were:

Speed 0 , rest

$$
\begin{aligned}
& \mathrm{I}, 24.3 \mathrm{~m} / \mathrm{min}(0.9 \mathrm{I} \mathrm{miles} / \mathrm{h}) \\
& 2,48.5 \mathrm{~m} / \mathrm{min}(\mathrm{I} .8 \mathrm{I} \mathrm{miles} / \mathrm{h})
\end{aligned}
$$

and the three gradients were:

$$
\begin{array}{rr}
\text { Gradient A, horizontal ( } & 0^{\circ} \text { elevation) } \\
\text { B, I in } 22 & \left(2^{\circ} 43^{\prime} \text { elevation }\right) \\
\text { C, I in I } 1 & \left(5^{\circ} \circ 7^{\prime} \text { elevation }\right)
\end{array}
$$

Each of the nine combinations of speed and gradient was imposed for 2 consecutive days, making a total of 18 days of observation for each sheep in each feeding period, and a total of 144 days of observation for both sheep.

\section{RESULTS}

Apparent digestibility of food. The design of the experiment did not permit separation of the effect of work on faecal losses, but comparisons can be made between the effects of the two levels of feeding. The apparent digestibility of the dry matter, C, N and energy of the dried grass cubes used in the experiment is presented in Table 2. The two animals appeared to behave differently. With sheep $\mathrm{H}$ there was no evidence that level of feeding affected the apparent digestibility of any constituent of the food except $\mathrm{N}$, for which there was an apparent increase, but with sheep J a lower apparent digestibility of all constituents except $\mathrm{N}$ was associated with increased intake of food.

Table 2. Apparent digestibility ( $\%$ ) of various dietary constituents by two shecp receiving pelleted dried grass at low and high levels of feeding

$\begin{array}{lcccc}\begin{array}{c}\text { Dietary } \\ \text { Constituent }\end{array} & \text { Low level } & \text { High level } & \text { Low level } & \text { High level } \\ \text { Dry matter } & 66.8 & 65 \cdot 3 & 67 \cdot 1 & 61 \cdot 5 \\ \text { Carbon } & 67 \cdot 2 & 66 \cdot 1 & 66 \cdot 9 & 6 \mathrm{r} \cdot 7 \\ \text { Nitrogen } & 60.4 & 65 \cdot 7 & 66.8 & 66 \cdot 8 \\ \text { Energy } & 65.9 & 65.7 & 67.8 & 63.5\end{array}$

Methane production. The methane production of the sheep is shown in Table 3 . Methane production $/ 100 \mathrm{kcal}$ food was (mean value with its SE) $6.97 \pm 0.06 \mathrm{kcal}$ at the lower feeding level and at the higher level was $4.78 \pm 0.06 \mathrm{kcal}$. This difference was significant. As in previous experiments (Clapperton, 1964), the imposition of a work load did not result in a significant increase in methane production compared with that produced at rest. Similarly, the effect of the imposed work load on the methane production during the following night was very small. There was a slight fall, but again the effect was not significant. The total daily methane production was not affected by exercise.

On an hourly basis the amount of methane produced during the day was always greater than that produced during the night. One feed was given during each period and the associated increase in methane production with feeding probably accounted for much of this difference. 
Urinary $N$. The mean value with its SE for daily loss of $\mathrm{N}$ in the urine was $6.59 \pm 0.26 \mathrm{~g}$ at the lower level of feeding and $9.62 \pm 0.26 \mathrm{~g}$ at the higher level. These values were significantly different. There were no other statistically significant effects. The imposition of a work load did not increase the amount of $\mathrm{N}$ excreted in the urine.

Urinary energy. The loss of energy in the urine amounted to $3.65 \mathrm{kcal} / 100 \mathrm{kcal}$ ingested. There were no differences in this value either between the sheep or between the levels of feeding.

Table 3. Methane production of two sheep on days on which they walked or did not walk measured during the $8 h$ in which any exercise was taken, during the remaining $16 h$ of the day when no exercise was taken and over the whole day. The values are expressed as if each period lasted $24 h$ and the values for walking are the means of observations at two speeds and three gradients

$\begin{array}{lllcc}\text { Activity of sheep } & \text { Sheep } & \begin{array}{c}\text { During the } \\ \text { first } 8 \mathrm{~h} \\ \text { (kcal/100 kcal food ingested) }\end{array} & \begin{array}{c}\text { During the } \\ \text { next } 16 \mathrm{~h}\end{array} & \begin{array}{c}\text { Over the } \\ \text { whole }\end{array} \\ \text { No walking } & \text { H } & 6.32 & 5.62 & 5.85 \\ & \text { J } & 6.24 & 5.59 & 5.81 \\ \text { Walking during day } & \text { Mean } & 6.28 & 5.61 & 5.83 \\ & \text { H } & 6.5 \mathrm{I} & 5.53 & 5.88 \\ & \text { J } & 6.38 & 5.56 & 5.79 \\ & \text { Mean } & 6.44 & 5.55 & 5.84\end{array}$

Table 4. Energy expenditure (kcal/min) by two sheep during the day when any exercise was taken and during the night when no exercise was taken, and the time spent lying expressed as a percentage of the time interval when no exercise was taken

\begin{tabular}{|c|c|c|c|c|c|c|}
\hline \multirow[b]{3}{*}{ Sheep } & \multirow{2}{*}{\multicolumn{2}{|c|}{ Work load }} & \multicolumn{2}{|c|}{ Energy expenditure } & \multirow{2}{*}{\multicolumn{2}{|c|}{ Time spent lying }} \\
\hline & & & \multirow{2}{*}{$\begin{array}{l}\text { During day } \\
\text { when work } \\
\text { load was } \\
\text { imposed }\end{array}$} & \multirow{2}{*}{$\begin{array}{l}\text { During night } \\
\text { when no } \\
\text { work } \\
\text { was done }\end{array}$} & & \\
\hline & Speed & Gradient & & & $\begin{array}{l}\text { During } \\
\text { day }\end{array}$ & $\begin{array}{c}\text { During } \\
\text { night }\end{array}$ \\
\hline \multirow[t]{7}{*}{$\mathbf{H}$} & \multicolumn{2}{|c|}{ No work } & 1.00 & 1.08 & 84 & 87 \\
\hline & I & None & $1 \cdot 39$ & 1.06 & - & 88 \\
\hline & (lower) & $1: 22$ & 1.44 & I.04 & - & 88 \\
\hline & & I $: \mathbf{I I}$ & $\times 62$ & 1.03 & - & 88 \\
\hline & 2 & None & 1.63 & 1.05 & - & 90 \\
\hline & (higher) & I: 22 & I. 98 & 1.06 & - & 88 \\
\hline & & $\mathbf{I}: \mathbf{I} \mathbf{I}$ & $2 \cdot 34$ & 1.09 & - & 87 \\
\hline \multirow[t]{7}{*}{ J } & \multicolumn{2}{|c|}{ No work } & 0.84 & 0.86 & 80 & 89 \\
\hline & \multirow{3}{*}{$\begin{array}{c}\mathrm{I} \\
\text { (lower) }\end{array}$} & None & $I \cdot 15$ & 0.84 & -- & 90 \\
\hline & & $1: 22$ & $1 \cdot 29$ & 0.87 & -- & 91 \\
\hline & & $I: I I$ & $1 \cdot 42$ & 0.90 & - & 88 \\
\hline & \multirow{3}{*}{$\stackrel{2}{2}$} & None & $1 \cdot 49$ & 0.87 & - & 85 \\
\hline & & $1: 22$ & $x \cdot 66$ & 0.89 & - & 90 \\
\hline & & I $:$ I I & $1 \cdot 79$ & 0.86 & -- & 88 \\
\hline
\end{tabular}

Heat production and behaviour of sheep. The mean heat production of the sheep during the day and during the night is shown in Table 4. This table also shows the proportion of the total time that the sheep spent lying. 
The results show that the imposed work load during the day did not affect the heat production during the following night. Nor did it increase the proportion of the total time spent lying. The work, therefore, did not overtire the animals causing them to spend more time lying and consequently to produce less heat.

The animals spent a greater proportion of time standing during the day on which they did not work than during the nights. This difference may bear some relation to the time spent eating, since one meal was given during each period and the periods were of unequal length. Part of the difference may also be due to the fact that the sheep were disturbed by the noise of people moving about in the room outside the respiration chamber during the day.

Energy retention. Energy retentions calculated from determinations of the energy in the food and excreta and the heat productions of the sheep did not differ significantly in any of the experiments from those calculated from the retentions of $\mathrm{C}$ and $\mathrm{N}$. The two values were, therefore, averaged and are shown in Table 5.

Table 5. Mean energy retained $(k c a l / 24 h)$ by two sheep at two levels of feeding when walking at different speeds on different gradients

\begin{tabular}{cl}
$\overbrace{\text { Speed }}$ Work load \\
\multicolumn{1}{c}{ No work } & None \\
(lower) & $1: 22$ \\
& $1: 11$ \\
2 & None \\
(higher) & $1: 22$ \\
& $1: 11$
\end{tabular}

\begin{tabular}{|c|c|}
\hline \multicolumn{2}{|c|}{ Sheep H } \\
\hline $\begin{array}{l}\text { Low-level } \\
\text { feeding }\end{array}$ & $\begin{array}{l}\text { High-level } \\
\text { feeding }\end{array}$ \\
\hline $\begin{array}{r}169 \\
23\end{array}$ & $\begin{array}{l}924 \\
8_{41}\end{array}$ \\
\hline $\begin{array}{r}-25 \\
-114\end{array}$ & $\begin{array}{l}729 \\
656\end{array}$ \\
\hline $\begin{array}{l}-172 \\
-273 \\
-477\end{array}$ & $\begin{array}{l}628 \\
468 \\
350\end{array}$ \\
\hline
\end{tabular}

$\begin{array}{cc}\begin{array}{c}\text { Low-level } \\ \text { feeding } \\ \text { 17I }\end{array} & \begin{array}{c}\text { High-level } \\ \text { feeding }\end{array} \\ \mathbf{2 3} & \mathbf{9 4 5} \\ -39 & \mathbf{8 2 8} \\ -118 & 703 \\ -147 & 636 \\ -236 & 628 \\ -261 & 548 \\ -263 & 433\end{array}$

Energy was retained at the lower feeding level when no work was done. This result vitiates any comparison of the apparent cost of muscular work when the animal was storing energy with that when the animal was drawing on its reserves of energy such as that made in a previous paper (Clapperton, I964), because there was a change from energy retention to energy loss when the work load was imposed.

Apparent energy cost of horizontal locomotion. The apparent cost of horizontal locomotion was calculated from the decrease in energy retention when the sheep were resting from that when they were walking on the level treadmill. The cost was then expressed as the number of calories required to move I $\mathrm{kg}$ of body-weight $\mathrm{I} \mathrm{m}$ horizontally (cal/hor. $\mathrm{kg} \mathrm{m}$ ). The results are presented in Table 6 .

The apparent cost of horizontal locomotion was greater at the higher speed for both sheep. This difference was statistically significant and agrees with the results of Smith (1922) who found that the energy cost of horizontal locomotion in man increased with increasing speed of walking. The apparent cost of level walking was greater at the lower level of feeding than at the higher but this effect was not statistically significant. There were no significant differences between the cost of work done by the two sheep.

The results show that the mean apparent cost of horizontal work was $0.59 \pm 0.03$ $\mathrm{cal} / \mathrm{hor}$. $\mathrm{kg} \mathrm{m}$. This value may be compared with similar values obtained by Brody 
( 1945$)$ for horses $(0.39 \mathrm{cal} / \mathrm{hor} . \mathrm{kg} \mathrm{m})$ and for cattle $(0.46 \mathrm{cal} / \mathrm{hor} . \mathrm{kg} \mathrm{m})$. The corresponding value for man is $0.54 \mathrm{cal} / \mathrm{hor} . \mathrm{kg} \mathrm{m}$ (Smith, r922) and for dogs $0.59 \mathrm{cal} /$ hor. $\mathrm{kg} \mathrm{m}$ (Lusk, 193I).

Table 6. Energy cost (cal/hor. $\mathrm{kg} \mathrm{m}$ ) of walking on the horizontal at two levels of feeding

\begin{tabular}{|c|c|c|c|c|c|}
\hline \multirow{2}{*}{$\begin{array}{l}\text { Speed of } \\
\text { walking }\end{array}$} & \multicolumn{2}{|c|}{ Low-level feeding * } & \multicolumn{2}{|c|}{ High-level feeding* } & \multirow[b]{2}{*}{ Mean } \\
\hline & Sheep $\mathbf{H}$ & Sheep J & Sheep $H$ & Sheep J & \\
\hline $\begin{array}{l}\text { Lower } \\
\text { Higher }\end{array}$ & $\begin{array}{l}0.577 \\
0.673\end{array}$ & $\begin{array}{l}0.649 \\
0.698\end{array}$ & $\begin{array}{l}0.328 \\
0.584\end{array}$ & $\begin{array}{l}0.513 \\
0.695\end{array}$ & $\begin{array}{l}0.517 \pm 0.037 \\
0.663 \pm 0.037\end{array}$ \\
\hline $\begin{array}{l}\text { Mean for walking } \\
\text { on the level }\end{array}$ & \multicolumn{2}{|c|}{$0.649 \pm 0.037$} & \multicolumn{2}{|c|}{$0.530 \pm 0.037$} & \\
\hline
\end{tabular}

Table 7. Energy cost (cal/ver. $\mathrm{kg} m$ ) of lifting I $k g$ body-weight I $m$ vertically by two sheep at two levels of feeding, when walking on two gradients and at two speeds

\begin{tabular}{|c|c|c|c|c|c|c|}
\hline \multicolumn{2}{|c|}{ Work load } & \multicolumn{2}{|c|}{$\begin{array}{l}\text { Low-level } \\
\text { feeding* }\end{array}$} & \multicolumn{2}{|c|}{$\begin{array}{l}\text { High-level } \\
\text { feeding* }\end{array}$} & \multirow[b]{2}{*}{ Mean } \\
\hline Speed & Gradient & Sheep $H$ & Sheep J & Sheep H & Sheep J & \\
\hline $\begin{array}{c}\mathrm{I} \\
\text { (lower) }\end{array}$ & $\begin{array}{l}1: 22 \\
1: 11\end{array}$ & $\begin{array}{l}4.17 \\
5.96\end{array}$ & $\begin{array}{l}5.99 \\
6.81\end{array}$ & $\begin{array}{l}9 \cdot 74 \\
8.04\end{array}$ & $\begin{array}{r}12.08 \\
9.28\end{array}$ & $7 \cdot 76 \pm 0.45$ \\
\hline$\stackrel{2}{2}$ & $\begin{array}{l}I: 22 \\
I: I I\end{array}$ & $\begin{array}{l}4.39 \\
6.63\end{array}$ & $\begin{array}{l}4 \cdot 30 \\
2 \cdot 75\end{array}$ & $\begin{array}{l}6 \cdot 96 \\
6 \cdot 04\end{array}$ & $\begin{array}{l}3 \cdot 86 \\
4 \cdot 71\end{array}$ & $4.96 \pm 0.45$ \\
\hline Mean & & $5 \cdot 13$ & \pm 0.45 & $7 \cdot 59$ & 0.45 & \\
\hline
\end{tabular}

- Values are the means of four estimates and have a SE of $\pm 1 \cdot 26 \mathrm{cal} / \mathrm{ver} . \mathrm{kg} \mathrm{m}$.

Apparent energy cost of walking on gradients. The results, shown in Table 7 , were calculated from the decrease in energy retention caused by walking on the inclined treadmill as compared with the energy retained in horizontal walking. They are expressed as the number of calories expended in raising $\mathrm{I} \mathrm{kg}$ of body-weight $\mathrm{I} \mathrm{m}$ (cal/ver. $\mathrm{kg} \mathrm{m}$ ). The energy cost of vertical work was the same for both sheep, but the cost was apparently greater at the lower speed and at the higher level of feeding. Both these effects were statistically significant.

The mean cost (with its SE) of vertical work was $6 \cdot 36 \pm 0.32 \mathrm{cal} / \mathrm{ver} . \mathrm{kg} \mathrm{m}$. The mechanical equivalent of heat is $2.34 \mathrm{cal} / \mathrm{ver}$. $\mathrm{kg} \mathrm{m}$. Therefore the efficiency of these sheep for vertical work was $36 \cdot 8 \pm 1.4 \%$. In experiments with man, Smith (1922) found the efficiency of vertical work in comparable experiments to be $33 \%$.

\section{DISCUSSION}

The experiments show that the heat production of the sheep at night was unaffected by considerable differences in their energy expenditure by day. A change in the energy expenditure during the night could have happened for two reasons. First, if the animals had failed to recover from the effects of the imposed work load and hence entered the night period in a state of oxygen debt, an increase in the heat output calculated from the gaseous exchange would be expected. In fact, care was taken to ensure that the animals always ended the walking period at least $20 \mathrm{~min}$ before the end of the $8 \mathrm{~h}$ day period. If, in any experiment, the animals had been in oxygen 
debt, then they were able to discharge this debt within $20 \mathrm{~min}$. Secondly, if the animals had become tired during the work period, it might cause them to take more rest during the night which could lead to a lower energy expenditure during the night. Since there was no change in the energy expenditure during the night after walking during the day neither of these reactions seems to have occurred but it is possible that both effects occurred simultaneously and masked any effect of exercise upon the heat production during the night.

The interesting feature of the results relating to the length of time that the sheep spent lying at night is the magnitude of the values. The animals lay for $88 \%$ of the time available to them. This value may be compared with the results obtained by Forbes, Braman \& Kriss ( 1930 ) who found that two steers receiving a ration about $\mathrm{I} \frac{1}{2}$ times the maintenance level lay for $73 \%$ of the $24 \mathrm{~h}$. Apart from standing for essential purposes such as eating, drinking, defaecation and urination, the animals in this experiment seemed to lie for the remainder of the rest period.

The energy cost of horizontal walking appeared to increase with speed. This result agrees with those of Smith (1922) who found with man that above a speed of $80 \mathrm{~m} / \mathrm{min}$ the energy cost of horizontal locomotion increased with increasing speed. The result is also in agreement with Durig's ( 1899 ) concept of a 'maximum economic velocity' above which the cost of unit work increases.

The results show that the energy cost of raising the body $\mathrm{I} \mathrm{m}$ is not affected by the gradient upon which the sheep is walking but that increase in speed cuts the cost of raising the body. In this respect, however, the sheep have reacted differently. With sheep $\mathrm{H}$, an increase in speed caused an increase in the apparent cost of vertical work whereas with sheep J there was a marked decline. Smith (I922), in experiments with men, found that the energy cost of raising the body increased as walking speed increased and that the cost fell as the grade increased. These results may show that different animals react differently to changes in rates of work.

In these experiments, the energy cost of horizontal locomotion was measured as the decrease in energy retention during walking compared with that at rest, and rest in these experiments involved lying for $88 \%$ of the time. The energy cost of walking is usually expressed as the increment in energy expenditure over the energy expenditure in standing. Blaxter \& Joyce (1963) have estimated that for the sheep the cost of standing is about $\mathrm{I} \cdot 7 \mathrm{kcal} / \mathrm{kg}$ body-weight $24 \mathrm{~h}$. If allowance is made for the time that the animals were forced to stand, whilst walking, the cost of horizontal work measured as an increment over the cost of standing becomes $0.54 \mathrm{cal} / \mathrm{hor}$. $\mathrm{kg} \mathrm{m}$. This is exactly the value quoted by Smith (1922) for man. The calculation of the cost of work of ascent is based upon the difference between two work loads. The cost of standing is thus already included in the cost of horizontal work and no correction is therefore necessary.

The absolute efficiency of these sheep for work of ascent was $36 \cdot 8 \pm 2 \cdot 6 \%$, a value which agrees with many previous results which indicate that the efficiency of most animals for both work of ascent and for work done in load-pulling is about $33 \%$. This figure implies that, of the energy expended in muscular work, one-third is expended on the environment and two-thirds appears as heat within the tissues. 


\section{SUMMARY}

I. The energy metabolism of two sheep was measured when they were resting and when they were walking on the level and on gradients of $I$ in 22 and $I$ in II. Two walking speeds were used, 24 and $48 \mathrm{~m} / \mathrm{min}$. The effect of exercise during the first part of the day upon the metabolism during the remainder of the day when the sheep were rested was also measured.

2. Exercise under the conditions of the experiments had no effect upon the methane production or urinary nitrogen excretion of the animals.

3. Exercise over an $8 \mathrm{~h}$ period did not affect the heat production of the sheep during a following $16 \mathrm{~h}$ period of rest. During $88 \%$ of the rest period the animals lay down.

4. The apparent cost of horizontal locomotion was $0.59 \pm 0.03 \mathrm{cal} / \mathrm{hor} . \mathrm{kg} \mathrm{m}$. If, however, an allowance for the cost of standing is made, the apparent cost of horizontal locomotion is reduced to $0.54 \mathrm{cal} / \mathrm{hor}$. $\mathrm{kg} \mathrm{m}$. The apparent cost of horizontal locomotion increased with speed.

5. The apparent cost of vertical work was $6.36 \pm 0.3^{2} \mathrm{cal} / \mathrm{ver} . \mathrm{kg} \mathrm{m}$. The apparent energetic efficiency of the sheep in doing vertical work was $36 \cdot 8 \pm \mathrm{r} \cdot 4 \%$. These results agree with values found for other species.

I am grateful to Dr K. L. Blaxter for helpful criticism and advice during the course of the experiments.

\section{REFERENCES}

Blaxter, K. L. \& Joyce, J. P. (1963). Brit. F. Nutr. 17, 523.

Brody, S. (1945). Bioenergetics and Growth, p. 912. New York: Reinhold Publishing Corp.

Clapperton, J. L. (1964). Brit. F. Nutr. 18, 39.

Durig, L. (I 899). Quoted by Smith, H. M. (I 922).

Forbes, E. B., Braman, W. W. \& Kriss, M. (1930). F. agric. Res. 40, 37.

Lusk, G. (1931). Elements of the Science of Nutrition, $4^{\text {th }}$ ed., reprinted, p. 43 I. London: Saunders.

Smith, H. M. (1922). Publ. Carneg. Instn, no. 309. 